\title{
The historical accentuation of masculine nouns in Čakavian and Štokavian Dalmatian dialects in light of Deanović's Lingvistički atlas Mediterana
}

\author{
JOSEPH SCHALLERT \\ University of Toronto, Department of Slavic Languages and Literatures, \\ 121 St. Joseph St., Alumni Hall 431, Toronto, ON M5S 1J4, Canada, \\ joseph.schallert@utoronto.ca
}

\begin{abstract}
Projekt Lingvistički atlas Mediterana Mirka Deanovića je privedel do objave številnih člankov med letoma 1958 in 1967, posvečenih leksiki bosanskih, hrvaških in srbskih narečij, ki se raztezajo na območju dalmatinske obale in otokov od čakavskega Krka na severu do staroštokavske Boke Kotorske na jugu. Ker so bili podatki zbrani z ozirom na prozodične značilnosti, je lahko Deanovićevo gradivo uporabljeno tudi za namen tega članka, ki prinaša primerjalne zgodovinske analize naglaševanja enozložnih moškospolskih osnov, potrjenih v Deanovićevem korpusu. Rezultati teh analiz na novo osvetljujejo leksiko in geografsko področje naglasnega tipa $d \mathrm{v}$ bosanskih, hrvaških in srbskih narečjih; gre za tematiko, ki je bila v središču znanstvenih razprav, posvečenih dokazovanju praslovanskega naglasnega tipa $d$ in njegovemu nasprotovanju.
\end{abstract}

Mirko Deanović's Lingvistički atlas Mediterana project led to the publication of a series of articles (1958-1967) devoted to the lexicon of a range of BCS dialects extending along the Dalmatian coast and offshore islands from Čakavian Krk in the north to Old Štokavian Boka Kotorska in the south. Since the data were gathered with due attention to prosodic details, Deanović's material can be utilized for the purposes of the present paper, which provides a comparative historical analysis of the accentuation of monosyllabic masculine stems attested in Deanović's corpus. The results of this analysis shed new light on the lexical and geographical domain of "accent type D" in BCS, a topic which has been the focus of scholarly discussion devoted to the evidence for and against Common Slavic "accent paradigm (d)".

Ključne besede: bosansko-hrvaško-srbska narečja Dalmacije, čakavsko in Zeta-Lovćensko naglaševanje samostalnikov moškega spola, praslovanski naglasni tip d, bosansko-hrvaško-srbski naglasni tipi kot refleksi praslovanskih paradigem

Key words: BCS dialects of Dalmatia, Čakavian and Zeta-Lovćen accentuation of masculine nouns, Common Slavic accent paradigm (d), BCS accent types as reflexes of Common Slavic paradigms 


\section{Comparative historical background}

The present study seeks to incorporate the relevant data from Mirko Deanović's Lingvistički Atlas Mediterana project (see sec. 2) into the investigation of the accentuation of masculine nouns in BCS (Bosnian-Croatian-Serbian) dialects of the Dalmatian coast (both Čakavian and Štokavian). ${ }^{1}$ An object of particular interest will be the evidence for a possible fourth Common Slavic (CSl) accentual paradigm, AP (d) (also known as "Illič-Svityč's archaism"), a topic which has drawn a considerable amount of attention from Slavic accentologists in recent decades (see notably Illič-Svityč 1963, Bulatova et al. 1988, Dybo et al. 1990, 1993, Vermeer 1984, 2002, Langston 2006, 2007, Schrager 2011). The contested status of AP (d) stands in marked contrast to the firmly established pedigree of the three paradigms reconstructed by Stang (1957), which are described below. Because the scholarly debate concerning AP (d) has so many dimensions, an adequate discussion even of those matters pertaining specifically to BCS (notably Čakavian) would be impossible here. I will reserve such a discussion for a later date, at which time I intend to show that a sufficient amount of the Čakavian (and south Štokavian) evidence is compatible with an approach which incorporates AP (d) into the CSl system to justify the retention of this paradigm as a term of reference when discussing the diachronic prosody of these particular derived systems.

The three generally accepted CSl accentual paradigms (AP) and the BCS accentual types (AT) which constitute their reflexes in masculine nouns are as follows: ${ }^{2}$

- AP (a): fixed "barytonic" root stress with acute intonation, cf. *gädb, *gäda $>$ AT-A BCS, Novi (Čak.) gäd, gäda. ${ }^{3}$

- AP (b): root stress with short or long neoacute intonation in the $\mathrm{N} \mathrm{sg.} \mathrm{+} \mathrm{post-}$ root "oxytonic" stress in most oblique case forms, cf. CSl short-vowel stem *pòpz, *popá > AT-B BCS pöp, pòpa, Novi (Čak.), pöp, popä, Prčanj (Boka Kotorska, archaic Old Štok.) pöp, N pl. popï; CS1 long vocalic root *grẽ̃x,

${ }^{1}$ According to the classification proposed by Vermeer (1982) and further elaborated by Langston (2006: 14-18), Čakavian dialects can be optimally subdivided into Northwest (NWČ), Central (Cᄃ̌), and Southeast (SEČ) subgroups on the basis of prosodic features (such as the presence of neo-circumfex lengthening), morphology (e.g., fem. gen sg. $-i<$ $*-y$, rather than $-e<*-e$ ), and the reflexes of jat' (ekavian, i-/jekavian, ikavian). For the pertinent Štokavian classification, see sec. 2.4.

${ }^{2}$ Note that the accentuation of the other forms of the sg. and in particular the pl. in AP (b), (c) and their BCS derivatives is by no means always identical to that of the G sg. form. ${ }^{3} \mathrm{BCS}=$ Bosnian-Croatian-Serbian (literary standards, cited as per the jekavian variant in Broz, Iveković 1901, unless indicated otherwise). Novi = NWČ dialect of Novî, as per Belić (1909). Accentual diacritics: " (CSl short falling pitch, BCS short falling pitch)," (CSl acute), (CSl short neo-acute, BCS short rising pitch), ` (CSl long circumflex, BCS long falling pitch), '(BCS long rising pitch), (CSl long neo-acute and Čakavian long rising pitch). For Čakavian prosody, see Langston 2006, 24-30 (overview), 31-70 (detailed description of NWČ types). 
*grěxá > AT-B (long neoacute in N sg. + reflex of oxytonesis in oblique cases) Novi grĩh, grīhä, Slavonian küt, kúta, AT-D (long falling pitch in N sg. + reflex of oxytonesis in other forms) BCS kût, kúta, grïjeh, grijèha, Prčanj prût, prütä. Thus, for most of BCS, AT-B > AT-D in long root stems due to the merger of neoacute with circumflex (prüt, prūtä > prût, prütä). In archaic Old Štokavian (and also some innovating Čakavian dialects), this merger results in a prosodic system with an opposition of quantity (long “ vs. short"), but without phonemic pitch oppositions, since the secondary prosodemes in pòpa and príta are generally the product of later stress retractions.

- AP (c): "mobile" stress (i. e., initial stress in "enclinomenal" forms with short or long circumflex intonation alternating with end-stress in "orthotonic" forms), cf. CSl short-vowel stem *bögъ, *ötı boga > AT-C BCS, Novi bôg, böga, öd boga; CSl long-vowel stem *kûmb, *zâ kuma > AT-C BCS, Novi kûm, zä kūma (vs. "orthotonic" *volsè̀xъ > Novi vlāsĩh). The lengthening of the CSl "circumflex" short vowel in the $\mathrm{N} \mathrm{sg}$. is a general feature of BCS, cf. *o, *e (rôd, röda, mêd, mëda) and even *ъ/b (dân).

It is important to note that in some varieties of standard BCS some of the original long-vowel oxytona from AP (b) have acquired AT-C in the sg. subparadigm due to the spread of long falling pitch to most of the oblique case forms (dijèla/déla $>$ dìjela/dêla). This development is likely the result of levelling with the the $\mathrm{N}$ sg. (dio/dëo), which would have served as the pivotal form for identification with the reflex of AP (c), cf. dïo/dëo, dïjela/dêla, (s)pûž, (s)püža, mlâdj, mlâdja. Typically, such nouns retain the oxytonic reflex in the plural, cf. mlijèčevi, etc., yielding the secondary type AT-CB (i.e., sg. C + pl. B). The reverse tendency (whereby nouns of AP [c] > AT-D) is far rarer and appears to occur more readily in $u$-stems (cf. mîr, míra, žîr

In contradistinction to the three generally recognized accent paradigms, AP (d) is a post-Stangian, "mixed" paradigm reconstructed by linguists of the Moscow Accentological School ${ }^{4}$ as possessing an enclinomenal N sg. circumflex reflex ( ${ }^{*} z \hat{q} b b$, as in AP $c$ ), but the reflex of AP (b) in the remaining forms (*zobá, etc.). In principle, a prototype such as AP (d) should yield AT-D (described above as a BCS reflex of AP [b] in long-vowel stems), cf. long-vowel stem *žêrbr, *bez žerbà 'lot; cork'> AT-D Čak (Brač) ždrîb, ždrībä vs. BCS AT-C ždrïjeb, ždrïjeba, short-vowel stem *rögъ, *rogá > Čak. (Susak) $r^{u} \hat{o} x$, royä, (Senj) drôb, drobä vs. BCS rôg, röga, drôb, dröba (but cf. also BCS grôm/gröm, gròma).

The diachronic interpretation of AT-D depends on the prosodic system of the given dialect. Thus, in the case of short-vowel CSI stems, AT-D is distinct from AT-B due to the difference in the length of the root syllable in the $\mathrm{N} \mathrm{sg}$. (cf. Susak böp, bobä). This difference is to varying degrees indistinguishable in dialects where secondary lengthening in closed syllables has obscured the dif-

\footnotetext{
${ }^{4}$ Notably Dybo, Nikolaev, Bulatova, and Zamjatina, who build upon earlier work by IlličSvityč (see References for details).
} 
ference, cf. AP (b) > Sali bộb/böb, bobä AT-D/B (as per Dybo et al. 1993: 107; for a critique of the type, see e. g., Langston 2007: 134). Generally in Čakavian dialects, this lengthening occurs in stems terminating in a sonorant, cf. $/ \mathrm{j}, \mathrm{v}, 1$, $\mathrm{m}, \mathrm{n}, \mathrm{r} /$, but in SEČ dialects it also occurs before voiced obstruents (e.g., Brač $b o \hat{b} b, d \hat{o} z \bar{z}$ and in many CČ dialects even before voiceless obstruents (e.g., Rab pop). ${ }^{5}$ More complicated still is the case of CSl long-vowel stems, where the potential distinction between the reflexes for AP (b) and (d) is theoretically detectable only in prosodically conservative Čakavian dialects (e.g., Novi, Vrgada, Hvar, Brač), which exhibit a reflex of the CSl neoacute in the N sg. (*dĩl, dìlä) separate from that of the circumflex (*list, listä), in contradistinction to a Cᄃ́ dialect such as Susak (Bulatova et al. 1988: 50; Vermeer 2001: 139, Langston 2006: 261; Kapović 2008: 7). Evidence for AT-D in long-vowel stems in such conservative dialects (even Senj which does have AT-D in short-vowel stems) is exceedingly rare, since we generally find AT-C as the reflex of AP (d) in Čakavian dialects of this type.

Bearing in mind the points addressed thus far, we now turn to the prosodic evidence for masculine nouns which can be culled from Deanović's lexical material.

\section{Deanović's Lingvistički atlas Mediterana (LAM) and its data}

The data for the present study are drawn chiefly from a series of 6 articles ${ }^{6}$ produced over a ten-year period by the eminent Croatian Slavist and Romance philologist Mirko Deanović in connection with the "Linguistic Atlas of the Mediteranean" (Lingvistički atlas Mediterana $=L A M$ ), a project which Deanovic himself conceived and initiated. ${ }^{7}$ As the Yugoslav linguist on the international team for LAM, Deanović (in some cases in collaboration with colleagues or assistants) investigated the following geographical points for inclusion in the LAM data base (arranged here from north to south on the eastern Adriatic coast): 1) Rovinj (Istria, non-Slavic); 2) Klimno (N Krk, NWČ) and Punat (S Krk, NWČ) (Deanović, Jelenović 1958); 3) Sali (Dugi Otok, CČ; Deanović 1967); 4) Komiža (Vis, SEČ; Deanović 1966); 5) Korčula (transitional Čakavian-Štokavian) and Lopud (north of Dubrovnik, Štokavian) (Deanović, Jelenović 1958); 6) Cavtat/

\footnotetext{
${ }^{5}$ For an informative survey of secondary lengthening in Čakavian, see Langston (2006: 104-118).

${ }^{6}$ Deanović and Jelenović 1958, Deanović 1958, 1962, 1963, 1966, 1967.

${ }^{7}$ Concerning the origin, scope, and history of the LAM project, see Deanović (1962: 5). The LAM questionnaire (upitnik) consists of the following chapters: Opći podaci (items $1-6=$ name of source village and neighboring villages, their inhabitants, main local body of water); I: More (7-29), II: Geomorfologija (30-60), III: Meteorologija (61-113), IV: Zvijezde (114-141), V: Navigacija i manovre (142-206), VI: Brodovi (207-375), VII: Život na brodu (376-417), VIII: Trgovina (418-435), IX: Ribanje (436-500), X: Fauna (501-786), XI: Flora (791-806).
} 
Vecchiaragusa (south of Dubrovnik, Štokavian; Deanović 1958); 7) Muo (Eastern Boka Kotorska, Old Štokavian; Deanović 1962). In order to render more precise the recording and/or verification of prosodic details during and immediately after his fieldwork, Deanovic had recourse to the collaborative assistance of various colleagues. ${ }^{8}$

Although the volume of data relevant to the stress of Slavic masculine stems to be found in this body of work is relatively small, it is of significant historical value, but with a small number of exceptions has not yet been adequately exploited by Slavic accentologists. ${ }^{9}$ The data is of particular prosodic importance for the information it provides on the lexical and geographical domains of AT-D as the reflex of AP (d), beginning with Krk in the north and extending beyond the southern frontier of Čakavian to include Zeta-Lovćen Štokavian dialects in the Boka Kotorska region.

For the purpose of discussing the accentuation of masculine nouns in Deanović's material, I have divided the dialects into the following subgroups (proceeding again from north to south): 1) NWČ (Klimno, Punat); 2) CČ (Sali) and SWČ (Komiža); 3) Neo-Štokavian (Cavtat, Lopud, Korčula); 4) Old Štokavian (Muo). In addition to the various criteria established by Vermeer (for Čakavian) and Rešetar (for Štokavian), this particular grouping is also based on the reflexation of nouns for which AP (d) is a possible reconstruction (as per Dybo et al. 1993: 106-111). All dialects are compared to standard BCS. Following the discussion of these individual systems, a full citation of the relevant data is provided in tabular form in the Appendix in order to facilitate comparison across the various dialects referred to in the text. Due to the particular focus of the present study, I will mainly cite CSl monosyllabic masculine stems for which both the N sg. and the G sg. (or I sg.) occur in Deanović's publications, since these are the critical forms for establishing the modern accent type. One exception is the $\mathrm{N} \mathrm{sg}$. for nouns of AP (a), since here the short falling pitch (and appropriate root vocalism) usually suffice to exclude the other paradigms. Fortunately, most of Deanović's lexical entries for nouns include both the $\mathrm{N}$ sg. and $\mathrm{G} \mathrm{sg}$. forms.

The list of nouns cited below for which AP (d) is a possible or variant reconstruction is as follows: ${ }^{10}{ }^{*} \operatorname{berg} b$ (d) 2,3 ; ${ }^{*}$ bokb (d) $1,2,3 ; *$ borb (b/d) 3; *brodb (d/c) 3; *bъrkъ (d) 3; *drobъ (c/d) 1, 3; *gromb (d/c) 3; *lovb (b/d) 3; *mostb (b/d) 3; * strojb (b/d); *torkb (d?); *versb (d) 2; *vbrxb (d) 1, 2, 3; *žerbs (d).

\footnotetext{
${ }^{8}$ For details, see sec. 2.1-2.4 below.

${ }^{9}$ For details, see the caption "Previous citations" at the beginnings of secs. 2.1-2.4 below.

${ }^{10}$ As per the convenient notation devised by Langston (2007: Appendix), the sources for the reconstructions are indicated as follows: $1=$ Bulatova et al. 1988, 2 = Dybo et al. 1990, $3=$ Dybo et al. 1993. For *strojb, *torkъ, and *žerbъ, see discussion in sec. 2.1 and 2.4.
} 


\subsection{Klimno (Northern Krk), Punat (Southern Krk): NWČ}

Abbreviations, sources: DJ $1958=$ Deanović, Jelenović 1958, K = Klimno (cited from DJ 1958), P = Punat (cited from DJ 1958). Prosodic collaboration: Although not explicitly indicated, the notation of prosodic details probably would have been entrusted to Jelenović (a dialectologist and native speaker of the Northern Krk dialect of Dobrinj). Previous citations: Vermeer (1982: 300) notes DJ 1958, but does not appraise its reliability or cite data. Incorporation into discussion of $A P(d):{ }^{11}$ none.

In terms of historical vocalism and prosody, DJ's data for Klimno and Punat are consistent with the general descriptions for Northern Krk and Sourthern Krk, respectively, as given by Lukežić and Turk (1998: 34-55 and 56-73). Despite certain differences in the development of their historical vocalism and the form of the G sg. fem. (e.g., K düga, -i 139, zimmä, -ï 148 vs. P zimä, - $\hat{e}$ 148), both dialects exhibit neo-circumflex lengthening in the present tense of $e$-verbs (Lukežić, Turk 1998: 54, 72; for Punat, see Vermeer 1984b: 277) a trait which is generally characteristic of NWČ (see Vermeer 1982). Klimno exhibits typical vocalic features of the Dobrinj regional dialect $\left(*_{b}>\mathrm{K}\right.$ döž, dožjä, râžōn, zvonä [*iz vъna], ${ }^{*} b_{2}>$ ogônj, vëtōr, -tra 137 vs. P vëtār, -tra 137, *l $>$ K pôž 161, *r > K, P črv 162). For Punat DJ (1958: 137) explicitly observe that every long $[\bar{a}]$ is pronounced as [ $\left.{ }^{\mathrm{u} a}\right]$ (e.g., $\left.v^{u} \hat{a} n k a\right)$, although for typographical reasons this feature is not indicated in their lexical entries. Neither dialect exhibits stress retraction or a distinct neoacute reflex. Pretonic length seems to be maintained in Klimno, but lost in Punat (e.g., K zimmä, -ï 148 vs. P zimä, -ê 148). Both dialects lengthen the old acute and short neoacute before sonorants in "new closed syllables", cf. AP (a) mêl, na krâj vs. räk, AP (b) kônj (for the latter, see Lukežić, Turk 1998: 54), but appear to lack secondary lengthening of the short neoacute before /ž/ (cf. *b $>\mathrm{K}$ döž, P däž, *e $*_{j e z z} \mathrm{vs}$. BCS jêž).

As to the accentuation of masculine nouns, the two dialects are in complete accord. The reflexes for AP (a), (b), and (c) are unremarkable except for K, P mlǐc AP (b?) (see discussion in sec. 2.3), cf. AP (a) KP krâj, na krâj, kräja, K, $\mathrm{P}$ krüh, K, P räk, K, P sîr, sïra; K vëtōr, -tra, P vëtār, -tra, K, P vläh 'čovjek z Velebita'; AP (a?) K mêl, mëla (P mêlo, -a); AP (b, short) K, P čêp, čepä, $\mathrm{K}$ döž, dožjä, P däž, dažjä, K, P jëž; K zvonä (*iz vъna); (b, long) mlâj, -ājä 'mlađ; new moon' ( $\neq$ BCS mlâdj, *mlâdja); AP (c) KP lôj, löja.

Less trivial is the prosodic behaviour of stems for which AP (d) is a possible or variant reconstruction. Here we find oxytonesis in 3 of 5 examples where standard BCS has AT-C, cf. TOT roots of AP (b/d) K, P möst, mostä (AT-B) BCS môst, mösta, K, P strôj, strojä (AT-D) BCS strôj, ströja; AP (c/d) K, P drôb, drobä (AT-D) BCS drôb, dröba; but agreement with BCS in the other

${ }^{11}$ By this I refer here and below to 1) the network of dialect points included in the Slavic Accentual Dictionary project (Dybo et al. 1993); 2) the critical discussion of AP (d) (Vermeer 2001, Langston 2006, 2007). 
2 examples, cf. AP (b/d) K, P bôr, böra, AP (c/d) K, P brôd, s brödōn. ${ }^{12}$ Note that brevity in möst is a strong indicator of AP (b), whereas in the context of NWC prosody the length in strôj might be secondary (due to stem-final sonorant), which allows theoretically for derivation from either (b) or (d). On the other hand, the final voiced obstruent in $d r o ̂ b$ is too low on the sonority scale to induce secondary lengthening in these dialects, which suggests an original circumflex and hence probably AP (d).

\subsection{Sali (Dugi Otok, CČ), Komiža (Vis, SEČ)}

Abbreviations, sources: S(ali)-D = Sali (cited from Deanović 1967), S(ali)-B = Sali (cited from Dybo et al. 1993, as per E. Budovskaja's fieldwork), K = Komiža (cited from Deanović 1966). Prosodic collaboration: The material gathered in Sali by Deanović was checked for prosodic features by the dialectologist Božidar Finka, a native speaker of the Sali dialect, who also directed Deanović to appropriate informants (Deanović 1967: 34). In Komiža, Deanović was accompanied by Frano Čale to facilitate "precise notation" of the data, which were then further reviewed by Mate Hraste, a dialectologist and native of Brusje (Hvar) and Ranko Marinković, a writer and native of Vis (Deanovć 1966: 10). Previous citation: Langston (2006: 261, fn. 26) refers to D 1966, but does not cite examples. Some of Deanović's data for Komiža are also cited by Hraste and Šimunović (1979), but the latter source sometimes omits the important G sg. form (e. g., bûk 1979: 87 vs. bûk, bōkä in D 1966). In his discussion of the evidence for AP (d), Vermeer (2001: 143) also cites Deanović (1967: 36) as a source of "an example" for the "type plottplotä", but it should be noted that the actual forms in D 1967 are bôr, borä and bôk, bokä (both also valid candidates for AP [d]), whereas *plotb does not occur in Deanović's corpus. Incorporation into discussion of $A P(d)$ : Sali (all sources noted in fn. 10); Komiža (none).

Komiža is a conservatively "Cakavian" western Vis dialect (see Moskovljević 1972). According to Šimunović (1981: 264), Komiža possesses a Čakavian neoacute (e.g., pĩsmo, cvĩte, mõli 'mali', strôża), but the latter merges with long falling pitch in final syllables, including monosyllables (cf. pût, krîž, kolobûk, letî). ${ }^{13}$ This account is consistent with the testimony of the long-vowel $\mathrm{N} \mathrm{sg}$. for masc. stems of AP (b) in Deanović's material (cf. K dîl, spûz), although neoacute notations in other forms are rare, due to the paucity of relevant data (cf. K dõrse 'drž se'). ${ }^{14}$ Whereas Komiža exhibits little evidence of stress retraction (unlike Brač and Hvar), Sali-D attests barytonic variants in fem. and neut. stems of AP (b), cf. zvîzda/zvizdä 38, strîla/strīlä (munja) 37, vîno/vinnö 55. Komiža also exhibits a wide range of secondary lengthenings in D 1966 (cf. K dôz, dāzjä; ìspod nūzä; pāklä, bûb, drûzg, bōkä (as per bûk), bōrä (as per bôr), krôj, krâja kräja; jôgla 'igla' 23, vârc, vārcä), wider in fact than

\footnotetext{
${ }^{12}$ AT-C is also attested for *bokb in Dobrinj (Jelenović 1962) bôk 'strmina' 240, do vrh böka 237 (lacking in KP).

${ }^{13}$ Cf. pù:t, krì̀z, klobu:k, letì̀, as per the transcription used in the original source.

14 The Komiža dialect texts in Hraste and Šimunović (1979: III, 86-97) abound in neoacute examples.
} 
Sali-D, a dialect of the CČ type (cf. Sali-D däž, dažjä, päkla, bôr, borä, krâj, kräja), although length is lost in post-tonic position (cf. grëben). Of further note in Komiža are the following vocalic reflexes: 1) $\left.*_{b}, b>\breve{a} / \bar{a} ; 2\right) *_{o}>o / \bar{o}$; 3) $\bar{a}>\hat{o}$; 4) $\bar{o}>\bar{u}$; 5) in open syllable commonly $\breve{a}>\bar{a}, \breve{o}>\bar{o}$. Moskovljević (Moskovljević 1972: 109-110) draws attention to the wide variation in vocalic reflexes for Vis dialects in general.

Where both Sali-D and Komiža provide evidence for the accentuation of masculine nouns, the stress is identical in all examples. The same is also true for Sali-D and Sali-B, with the significant exception of the oxytonic G sg. variant in Sali-B for ${ }^{*} b r o d z$ (see below). It is also noteworthy that although Vis falls within the SEČ area, with respect to the reflex of AP (d) Komiža in D 1966 patterns prosodically rather as a Cᄃ dialect (perhaps of the less "extreme" variety), since most examples of "exceptional" oxytonesis for AP (d) are attested in dialects of the latter type, whereas the best-attested SEČ dialects (Vrgada to the north of Vis, as well as Brač and Hvar to the immediate east) never or but rarely exhibit AT-D. One interesting rarity in Deanović's data is the oxytonic plural in räk, racì in both Sali-D and Komiža (perhaps due to analogy with the short neoacute type *pöp, *popï).

As to the accentuation of masculine nouns, the reflexes for AP (a), (b), and the virtually unattested (c) are again unexceptional, although Komiža exhibits no penchant for shifting long stems of AP (b) into AT-C (a conservative trait shared with SEČ Brač and Hvar in contradistinction to BCS), ${ }^{15}$ cf. AP (a) S-D hömo üza krâj, od kräja, K krôj, krâja, nis krôj, Fōli môre, dõrse kräja (poslovica 'Hvali more a drž se kraja'); K lük; S-D, K räk, racï (sic!); S-D vïtar, vïtra, od vïtra; $\mathrm{K}$ vïtar, vïtra; $\mathbf{A P}(\mathbf{a}$ ?) $\mathrm{K}$ vârc, vārcä (with -ār $r$ - as reflex

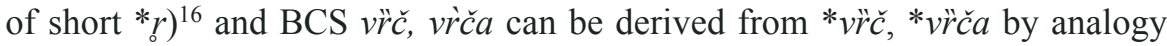
to the short neoacute type *pöp, *popä (as occurred in the case of mäk, màka)

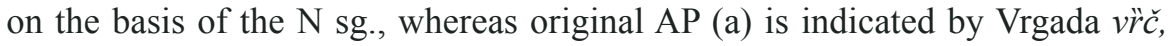
$-a, u$ v̈ř́u Jurišić 1975: 24 < Balkan Latin urceus, with variant *vbrčbva, as per *bъčbva (Skok III: 620-621); AP (b, short) S-D čêp, S-B čêp/čệp, čepä; S-D däž, dažjä, K dôz, dāzjä; S-D jê̌z; K ìspod nūzä (= BCS nôž, nóža) S-D pakâl, paklä 'smola', K pakôl, pāklä; S-D päs, pasä (*pbsъ); S-D vôl, volä; (b?) ${ }^{*} r_{t} t b>\mathrm{K}$ rôt, rōtä top. ( $\neq \mathrm{BCS} \hat{r} t$, *r̂ta); AP (b, long) K dìl, dīlä 'share of the catch', S-B dẹl, dēlä 107 ( $\neq \mathrm{BCS}$ dìjel, -a, dijèlovi); *spblžjb > K spûz,

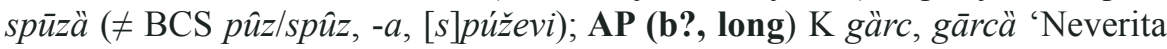
millepunctata; sea snail, mollusk', BCS gřčc, gřča 'cramp' (Skok 1971: I, 611612); AP (c) K, S-D danäs.

Stems with TOT root vocalism for which AP (d) is a possible reconstruction display oxytonesis in both Sali and Komiža in 2 stems for which BCS shows AT-C, cf. AP (d) S-D bôk, bokä 'zaljev', S-B bộk, bokä 162, K bûk, bōkä († BCS bôk, böka); AP (b/d) S-D bôr, borä, K bôr, bōrä, S-B (bộr, borä/böra,

${ }^{15}$ Regrettably, D 1967 provides no data from Sali for such nouns.

${ }^{16}$ According to Hraste and Šimunović (1979: XXIV), syllabic $*_{r}$ was dephonologized on

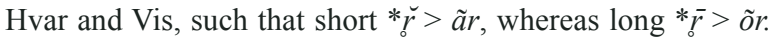


dat. borü, nom. pl. borï/böri 165 ( $\neq$ BCS bôr, böra). For 2 other stems in this class we find barytonesis, as in BCS: AP (c/d) S-D brôd, bröda, od bröda, z brödun, S-B *brộd, *bröda/brodä, K brûd, bröda, brûd je nõsal [našao] dnö, brûd peskô töko i töko, brûd tecë, od bröda, brödon; S-D drôb, dröba. Finally, for one stem (*grom $)$, we find the reverse correlation, whereby Sali and Komiža show AT-C where BCS itself exhibits AT-D, cf. AP (d/c) S-D grôm/grûn (arch.), grôm te ubî, gröma, K grôm, gröma (キ BCS grôm, gròma), but this "reverse" correspondence is common in Čakavian, cf. Novi grôm, gröma (Белић 1909: 209), Senj grôm, gröma (Moguš 2002: 27), Vrgada grôm, gröma i (Jurišić 1973: 65), Hvar (Brusje?) grôm, -öma (Hraste 1935: 18). ${ }^{17}$

The only long-vowel stem of $\mathbf{A P}(\mathbf{d})$ attested with both $\mathrm{N}$ sg. and $\mathrm{G}$ sg. offers comparatively rare BCS evidence for AT-D in this vocalic class, cf. Komiža

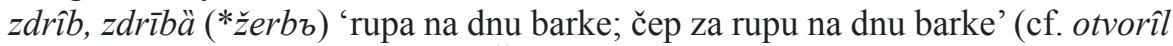
źdrîb na lnö [dno] bröda Hraste, Šimunović 1979: III, 95). It is noteworthy that we find the same reflex in at least one other SEČ dialect (Brač), for which AT-D as a reflex of AP (d) in long-vowel stems has not been observed in the scholarly literature. ${ }^{18}$ The remaining examples are less remarkable, cf. ${ }^{*} b$ brk (d) $>$ $\mathrm{K}$ bârk, bãrci od ostïjū 'moustache (fig.) on a harpoon' 22 (BCS brkk, *brka, pl. brkkovi/br̂ci), *torkъ AP (d?) trôk, trôci 'trak (od sipe, hobotnice)' 26 (BCS trâk, trâka, trâci/träkovi/trákovi), *vbrxъ (d) > vôrh 'oštra kvačica na udici' 22.

\subsection{Cavtat (Neo-Štok), Lopud (EHerz/Neo-Štok), Korčula (Čak-Štok)}

Sources, abbreviations: $\mathrm{C}=$ Cavtat (cited from Deanović 1958), $\mathrm{K}=$ Korčula (cited from Deanović, Jelenović 1958), L = Lopud (cited from Deanović, Jelenović 1958); Prosodic collaboration: Entrusted to Jelenović (Cavtat, see Deanović 1958: 5). Incorporation into discussion of $A P(d)$ : none.

In general, the prosodic data in Deanović, Jelenović 1958 for the jekavian dialects of Cavtat (10-15 km. SE of Dubrovnik) and Lopud (the penultimate southernmost island in the Dalmatian chain, situated immediately to the NW of Dubrovnik) conform to the East-Hercegovinian (Vukovian) Neo-Štokavian type of accentual system. The same is true for the ikavian dialect of Korčula, situated farther north in the chain and characterized by Deanović and Jelenović

${ }^{17}$ For further discussion, see Dybo et al. 1993: 202.

${ }^{18}$ Most likely the village of Dračevica, the native dialect of Šimunović, cf. ždrîb, ždrībä [Bč] (Hraste and Šimunović 1979: 140). In a later publication, Šimunović (2009: 1081) lists $\check{z} d r i ̂ b, \check{z} d r i ̂ b a$ [Bč], which appears to be either a misprint or an accidental citation of the Vrgada form to which reference is made in the same entry. AP (d) can be reconstructed on the basis of the correspondence AT-D [Komiža, Brač] AT-C in BCS ždrïjeb, ždrïjeba 'lot', cf. also Cres [Orlec] žrêp, žrêba, pl. źrêbi (Houtzagers 1986: 406); Vrgada ždrîb, -a (Jurišić 1973: 246), as well as the reflex of AP (c) or (d) in Ru (Fasmer) же́ребиŭ, Ukr же́реб, RuChSl жре́бий 'lot', i. e., 'something carved, notched', and brevity in Cz hřeb 'nail' (Fasmer II: 47-48) < PIE * gerbh- with short root vocalism (Skok 3: 672). 
as "transitional from Čakavian to Štokavian". One difference is that Lopud appears to lack the development of secondary length (at least before $-r$-) in the reflex of the old acute, cf. C sîr, K sîr, sïra L sïr.

An analogous general similarity to the BCS standard type can also be observed in the Cavtat, Lopud and Korčula data pertaining not only to the accentual reflexes of all the CSl AP's, but also to the lexical distribution of AT-C vs. AT-D as the reflex of stems for which AP (d) is a possible reconstruction, cf. AT-C in ${ }^{*}$ borb $(\mathrm{b} / \mathrm{d}),{ }^{*} \operatorname{brod} \mathrm{s}(\mathrm{d} / \mathrm{c})$, but AT-D in ${ }^{*}$ groms $(\mathrm{d} / \mathrm{c})$, the latter in contradistinction to the common Čakavian reflex AT-C. The only exception is *mostz, which exhibits AT-C in BCS, but AT-D in Lopuda and the oxytonic gen. sg. reflex in Korčula (which can reflect either AT-B or AT-D).

AP (a) C gräh 16; K, L krâj, kràja (sic!), nä kraj (secondary proclisis); K, L krüh, C rúka krüha, bùfet krüha; C räk, pl. räzi; K, L räk; C sïr, K sîr, sïra, L sïr, sîra; K vläh 'dalmatinski zagorac'; C vjëtar, vjëtra; K vïtār, -tra; L vjëtar, vjëtra; AP (b, short) C čëp öd barke; C däž, dàžda, K, L däž, dàžda; C jêz,

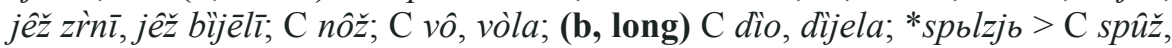
-úža, K, L spûži ; C tr̂n 23; AP (c) K, L lôj, löja; AP (cc) *versъ > C z vrïjesōm 'Erica, Calluna vulgaris'; AP (b/d) C bôr, böra, köra öd bora; K, L bôr, böra; K grözd; L môs, mòsta; K gen.? mòsta 140; AP (d/c) C brôd, bröda, öd broda, dat. brödu, z brödōm; K brôd, guvèrna(t) brödon; L brôd; L grôm, gròma; $\mathbf{A P}$ (c $\sim \mathbf{d}) \mathrm{L}$ čèsan, -sna 163; AP (d) C lîs, lîsta; L üzō, üzla; C dvâ rêda püzā na träkovima 'tentacles'.

The only long-vowel stem which exhibits variation is *melčjb AP (b?), where the irregular brevity in K mlïc ('rossetto Aphya pellucida; transparent goby fish') answers to that attested in Klimno and Punat (Krk, sec. 2.1), but contrasts with the usual neoacute reflex in L mlïječ, mlijèča (1) 'veleni da pesca; Euphorbia, spurge sap (milky and poisonous, used to catch fish)', cf. Brusje (Hvar), Dračevica (Brač) mlĩč, mlī̌că (Hraste, Šimunović 1979: 554), Cres mlêc, mlecä 'vrlo sitna riba' (Skok 1971: II, 442) vs. secondary (?) AT-CB in BCS mlïječ, mlïječa, pl. mlijèčevi, all derived from the root found in *melko AP (b).

\subsection{Muo, Prčanj, Lepetane: Boka Kotorska Old Štokavian}

Abbreviations, sources: M = Muo (Deanović 1962); P = Prčanj (Rešetar 1900), L = Lepetane (Tomanović 1936); Prosodic collaboration: In August of 1959, Deanović was accompanied by an assistant, Frano Čale (cf. also Komiža), whose explicit task was to pay particular attention to "accentuation and quantity" (Deanović 1962: 15); Previous citation: None in sources consulted. Incorporation into discussion of $A P(d)$ : none for Muo (or Lepetane).

The dialects of Boka Kotorska (Montenegro) can be divided into two distinct types: East Hercegovinian (the western shore) and Zeta-Lovćen (the eastern shore) (see Rešetar 1900: 18-21; Ivić 1958: 208, Skizze 22). The Zeta-Lovćen Montenegrin dialects of the eastern shore exhibit a considerable amount of local phonological variation (Deanović 1958: 10-11). Deanović's transcription of 
the Muo data captures neither the labialized reflex of $* \bar{a}\left(\mathrm{~N}\right.$ sg. m. def. $\left.s t^{\prime \prime} \hat{a r i}\right)$ (as in some Čakavian dialects) ${ }^{19}$ nor the $\ddot{a}$-reflex of the jers and shortened $* a$ däžd, daždä, which are described in the dialectological literature. ${ }^{20}$ The prosody is generally that of the archaic Old Štokavian type, as best represented in the speech of the Catholic population (Rešetar 1907: 19-20). This type is clearly reflected in Deanović's material for Muo, cf. mijēnä 'new moon', lìjēpo, dūgä, gen. dūgê, pünī mjësēe (M 20). In the G sg. of masc. nouns with AT-D, we find fluctuation in the notation of etymological ${ }^{*} o$ in the open pre-tonic syllable before voiced stops, cf. G sg. brōdä (brôd) drobä (drôb). There is no evidence for secondary lengthening of the old acute, cf. na dim, sirr.

Although mentioned in historical records dating back to the $14^{\text {th }} \mathrm{c}$., according to Deanović (1962: 14), Muo's present population attests no direct descendants of the original (starosjedilac) population, but rather those of settlers who arrived from Montenegro and other parts of Boka Kotorska in the $18^{\text {th }} \mathrm{c}$. during the period of Venetian rule. D cites an early $20^{\text {th }} \mathrm{c}$, study by Nikićenović, who determined that 10 of the local clans originated in Montenegro, one in Hercegovina, and the rest from Boka itself. In this connection, it is probably worth noting that one of the Montenegrin clan names seems to provide the last name of D's primary informant for Muo, Antun Marović (1889-?), a fisherman and shipwright by trade. Several other secondary informants are also mentioned.

In the Slavic Accentual Dictionary project (Dybo et al. 1993: 104) the region of Boka Kotorska is represented by the dialect of Prčanj, ${ }^{21}$ which is claimed to have reflexes for AP (d) identical to those of AP (c), with the important exception of secondary disyllabic stems, such as *mozgъ > Prčanj mozäk, moskä (a trait shared with dialects to the east of Boka, such as Belopavlići, Novi Pazar, and Piperi). This evidence is corroborated by the other principal source for Boka Kotorska prosody (the village of Lepetane, as per Tomanović 1937). ${ }^{22}$ It is interesting that Deanović's data for Muo actually provides more information

${ }^{19}$ Noted by Rešetar (1900: 104).

${ }^{20}$ See notably Rešetar (1907: 90, 104), Ivić (1958: 207-208, 219), and originally (for the non-standard jer-reflex generally in the region) Karadžić (1849: XVII). Deanović intended to provide a more detailed phonetic and phonological description of the Muo dialect material at a later date (1962: 14), but this plan regrettably never came to fruition.

${ }^{21}$ Prčanj served as the basis for Rešetar's description of the most archaic (unretracted) prosodic system in his classic study of SW Štokavian accentuation (Rešetar 1900, with a few additional data from Rešetar 1907). The principle exception occurs in stems with long root vocalism which often exhibit retracted variants (trûd, trūdä/trûda 54, krîz, krǐžä/ krîža 54; lïjek, lijekä/lìjeka 54; skût, skūtä/skûta 54, where the available evidence for Muo indicates greater conservatism).

22 In Lepetane historically oxytonic masculine stems with long root vocalism have merged with the reflex of the circumflex (thereby completing a process which seems to be in its initial phase in Prčanj and which is sporadically attested in the Vukovian norm as well),

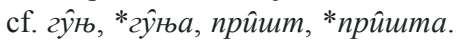


than the other two sources do for TOT roots. Unfortunately, the degree of lexical overlap in the data adduced by Rešetar and Deanović is comparatively small.

As in the other systems thus far described, the reflexes of AP (a), (b), and (c) in Muo are unexceptional, though one observes the shift to AT-C in *dělb, the only attested long-vowel stem of AP (b).

AP (a) M rïba osušêna na dìm; krâj, kräja 'obala, kopno', äjmo nis krâj, na krâj, bâva s kräja, marëte lūpaju o kräju; M räk, räka, pl. räki; M vjëtar, vjëtra; AP (b, long) M dìo lovä, dijēela ( $\neq$ Prč. dìo, dijelä, but = BCS Vuk dìo, dïjel, dïjela, aber djèlovi' Rešetar 1900: 53-54); ${ }^{23}$ AP (b, short) M čäp 'čep; plug, cork (on boat)', jêž, jěžä 33 ( $\neq$ Prč. jêž, jêža 53, as in BCS); M däžd, daždä (= Prč. däžd, daždä 46); M ìmā ardûrē kao ognjä; M papär, paprä 25; AP (c) M danäs 17, iz gnöja (crljëna glīstä ).

For monosyllabic masc. stems with TOT root vocalism and a possible reconstruction of AP (d), the Muo dialect is characterized by a much higher rate of oxytonesis (manifested as AT-D) than either standard BCS or the other attested Boka Kotorska Old Štokavian villages of Prčanj and Lepetane, cf. *brodb (d/c), *drobs (c/d) * groms (d/c) (all with reflex of AP (c) in Prč., Lep., cf. brôd, bröda, etc.), as well as *lovъ (c/d), *mostъ (b/d) (both unattested in Prč., Lep., but with the reflex of AT-C again in BCS). An important exception is *borz, at least insofar as both Muo and BCS exhibit AT-C, although here Prčanj and Lepetane exhibit AT-B (the usual reflex of AP [b]) rather than AT-D (contrast Mažuranić bôr, bòra, as cited in Rešetar 1900: 45). The incidence of AT-D in Muo also appears to be higher than the level attested in NWČ Klimno and Punat on Krk (cf. *brods, and arguably * gromb). Although there are no examples in Muo for short stems of unambiguous AP (d) (in Deanović's corpus, this would be *bokb, *rog $b$ ) the cases of *brodb, *drobb, and *groms would seem to provide a valid substitute, since the alternative to AP (d) here is AP (c), for which even CČ thus far attests no examples of AT-D in TOT roots within the corpus of reconstructions to be found in the publications of the Slavic Accentual Dictionary project.

AP (d/c) M ârmali smo brôd, brôd na dezârmu, ukrâmo se nä brōd, brôd peškâ tolìko, mâlī [od brōdä] 'mornarski početnik', družinä [od brōdä] (\# Prč. *brôd, *bröda, ${ }^{24}$ Lep. 70, BCS brôd, bröda), but cf. also provǐšta od bröda 25; AP (c/d) > M rïblji drôb, drobä ( $\neq$ Lep. *drôb, *dröba 70, BCS drôb, dröba); $\mathrm{M}$ grôm, gromä, grôm te ubïo (= BCS grôm, gròma, but $\neq$ Prč. grôm, gröma

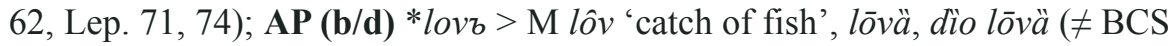

${ }^{23}$ But cf. also Prč. drïjen, drïjena 'hôrte ich nur drïjena' (sic Rešetar op. cit.), grïjeg, grïjega (*grěxz) 54.

${ }^{24}$ As per Rešetar (1900: 65), since these forms can be generated on the basis of Rešetar's discussion of pl. brödovi, cf. '...bleibt auch in diesem Faller der Akcent unverändert', listed together with nôs, nösa, nösovi, as well as rögovi, whose sg. stress is in fact not listed here, nor on pp. 45-46, although the entire chapter is devoted to 'Stämme mit Wurzelbetonung'. 
lôv, löva). For the contrary distribution, cf. AP(b/d) M bôr, böra 'Pinus pinea', bôr, böra 'Pinus maritima' ( $\neq$ Prč. bör, borä 45, Lep. бöp, бopä 74).

More remarkable, however, is the case of the long-vowel stem *bergb (d), which yields AT-D in Muo brijêg, brijeggä, ${ }^{25}$ despite the overwhelming predominance of AT-C in a wide variety of sources for BCS and its dialects, including Čakavian, with the exception of certain sources for CČ which report unusually high levels of AT-D (although the latter have been contested in the literature, notably Vermeer 2001, Langston 2006, 2007). When combined with the higher rate of AT-D in TOT roots compared to that which we find in Prčanj, the occurrence of this reflex in *bergb suggests that the ancestral dialect of Muo had its roots in a system heretofore undescribed for "Southern Štokavian" (as per the classification in Dybo et al. 1993), thereby lending further possible support to Ivić's theory regarding older connections between Zeta-Lovćen and KosovoResava dialects (Ivić 1958: 221-222), inasmuch as the authors of the Slavic Accentual Dictionary have proposed extensive relics of AP (d) for the Resava dialects (Dybo et al.1993: 100-104).

AP (b/d) *protı > M prût, prūtä (Prč. prût, prūtä 54, = BCS prût, prûta); AP (d) brijêg, brijēgä (Geomorfologija II: 60); M dvâ rêda; M strâv, strâva 'Schreck' (Rešetar 1907: 121).

\section{Conclusion}

Since I intend to integrate Deanović's material relating to AP (d) into a broader discussion of this problematic paradigm in a separate study, I here simply observe that this material corroborates the presence of AT-D in CČ dialects such as Susak, Sali, Senj, etc. in the following 5 short-vowel stems: 1) *bokъ (Komiža bûk, bokä, Sali-D bôk, bokä), 2) *borъ (Sali-D bôr, borä, Komiža bôr, bōrä); 3) *brods (Muo brôd, brōdä); 4) *drobs (Klimno, Punat, Muo drôb, drobä); 5) *lovb (Muo lôv, lôvä), as well as in the following two long-vowel stems: 1) *bergъ (Muo brijêg, brijēgä); 2) *žerbъ (Komiža zdrîb, zdrībä). In addition, Deanović's material allows us to expand the geographical range for AT-D to include NWČ (Krk), SEČ (Vis), and Boka Kotorska (Muo). Finally, the material from Muo also opens up a new avenue of exploration into ties between the Zeta-Lovćen and Kosovo-Resava dialects.

25 The transcription of jekavian forms such as brijêg varies in the accentual literature, cf. BCS brïjeg, - $a$, but also WCr Štok. drijên, drijêna (Vukušić 1984: 15), as well as brïjeg brijêg, brijêga (Schrager 2011: 37). 
APPENDIX:

Summary of accentual data for CSI monosyllabic masculine stems attested in the published materials for Deanović's Lingivistični Atlas Mediterana (Oxytonic forms and ostensible reflexes of AP [b], [d] are indicated in bold italics)

\begin{tabular}{|c|c|c|c|c|c|c|c|c|c|}
\hline \multirow{3}{*}{ CS1 } & $\begin{array}{c}\text { BCS } \\
\text { Standard }\end{array}$ & $\begin{array}{l}\text { Klim. } \\
\text { NKrk }\end{array}$ & $\begin{array}{l}\text { Punat } \\
\text { SKrk }\end{array}$ & $\begin{array}{c}\text { Sali } \\
\text { DOtok }\end{array}$ & $\begin{array}{c}\text { Komiž. } \\
\text { Vis }\end{array}$ & Korč. & Lopud & $\begin{array}{c}\text { Cavtat } \\
\text { Dubrov. }\end{array}$ & $\begin{array}{l}\text { Muo } \\
\text { BKot }\end{array}$ \\
\hline & Croat. & NWČ & NWČ & 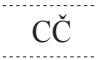 & SEČ & SČ-WŠ & WS & WS̆ & SWS \\
\hline & $\begin{array}{l}\text { Broz } \\
\text { Ivek. }\end{array}$ & $\begin{array}{c}\text { Dean. } \\
\text { Jelen. } \\
1958\end{array}$ & $\begin{array}{l}\text { Dean. } \\
\text { Jelen. } \\
1958\end{array}$ & $\begin{array}{l}\text { Dean. } \\
1967\end{array}$ & $\begin{array}{l}\text { Dean. } \\
1966\end{array}$ & $\begin{array}{l}\text { Dean. } \\
\text { Jelen. } \\
1958\end{array}$ & $\begin{array}{c}\text { Dean. } \\
\text { Jelen. } \\
1958\end{array}$ & $\begin{array}{l}\text { Dean. } \\
1958\end{array}$ & $\begin{array}{l}\text { Dean. } \\
1962\end{array}$ \\
\hline \multicolumn{10}{|c|}{ COMMON SLAVIC SHORT-VOWEL STEMS } \\
\hline $\begin{array}{c}\text { *серъ } \\
\text { B }\end{array}$ & $\begin{array}{l}\text { čèp } \\
\text { čèpa }\end{array}$ & $\begin{array}{l}\text { čèp } \\
\text { čppà } \\
142\end{array}$ & $\begin{array}{l}\text { čêp } \\
\text { cepepà } \\
142\end{array}$ & $\begin{array}{c}\text { čêp } \\
41\end{array}$ & & & & $\begin{array}{c}\check{c e ̀ p} \\
11\end{array}$ & $\begin{array}{c}\text { čäp } \\
22\end{array}$ \\
\hline$\underset{B}{* \mathrm{~d}_{\mathrm{b} z ̌ d j} \mathrm{~b}}$ & $\begin{array}{c}\text { (dâžd } \\
\text { däžda?) }\end{array}$ & $\begin{array}{c}\text { döž } \\
\text { dožjà } \\
138\end{array}$ & $\begin{array}{c}\text { däz } \\
\text { dažjā } \\
138\end{array}$ & $\begin{array}{c}\text { däz } \\
\text { dažjō } \\
37\end{array}$ & $\begin{array}{c}d \hat{o} z \\
d \bar{a} z j a ̄ a \\
14\end{array}$ & $\begin{array}{c}\text { dăž } \\
\text { dàz̆da } \\
138\end{array}$ & $\begin{array}{c}\text { dăž } \\
\text { dăz̆da } \\
138\end{array}$ & $\begin{array}{c}\text { dăz } \\
\text { dăz̆da } \\
8\end{array}$ & $\begin{array}{c}\text { dä̆̆d } \\
\text { daz̆dà } \\
19\end{array}$ \\
\hline $\begin{array}{c}* \text { *ježb } \\
B\end{array}$ & $\begin{array}{l}\text { jêžz, -a } \\
\text { jéževi }\end{array}$ & $\begin{array}{l}\text { jëě } \\
162\end{array}$ & $\begin{array}{l}\text { jëž } \\
162\end{array}$ & jêž & & & & jêž 25 & 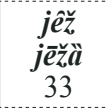 \\
\hline $\begin{array}{c}\text { *nožb }^{*} \\
\text { B }\end{array}$ & $\begin{array}{l}\text { nôz̆ } \\
\text { nóz̆a }\end{array}$ & & & & $\begin{array}{c}\text { ìspod } \\
\text { nūzä } \\
30\end{array}$ & & & nôž 16 & \\
\hline $\begin{array}{c}{ }_{\text {ognb }} \\
\mathrm{B}\end{array}$ & $\begin{array}{l}\text { oganj } \\
\text { ognja }\end{array}$ & & & & & & $\begin{array}{c}\text { ognja } \\
142\end{array}$ & & $\underset{18}{\text { ognjä }}$ \\
\hline $\begin{array}{c}{ }^{* p} \mathrm{p} b \mathrm{klb} \\
\mathrm{B}\end{array}$ & $\begin{array}{l}\text { pàkao } \\
\text { pàkla }\end{array}$ & & & $\begin{array}{c}\text { pakâl } \\
\text { paklä } \\
41\end{array}$ & $\begin{array}{c}\text { pakôl } \\
\text { pāklä } \\
18\end{array}$ & & & & \\
\hline $\begin{array}{c}{ }^{*} \mathrm{pbSb} \\
\mathrm{B}\end{array}$ & $\begin{array}{l}\text { päs } \\
\text { psä }\end{array}$ & & & $\begin{array}{c}\text { päs } \\
\text { pasä } \\
51\end{array}$ & & & & & \\
\hline $\begin{array}{c}\text { *rbtb } \\
\mathrm{B} ?\end{array}$ & $\begin{array}{l}\text { rt } \\
\text { rta }\end{array}$ & & & $\begin{array}{c}\text { rôt } \\
\text { rōtà } \\
13\end{array}$ & & & & & \\
\hline $\begin{array}{l}\text { *volb } \\
\text { B }\end{array}$ & $\begin{array}{l}\text { vô } \\
\text { vòla }\end{array}$ & & & $\begin{array}{c}\text { vol } \\
\text { volà } \\
52\end{array}$ & & & & $\begin{array}{c}\text { vôl } \\
\text { vòla } \\
23\end{array}$ & \\
\hline $\begin{array}{c}{ }_{\mathrm{vbn}} \\
\mathrm{B}\end{array}$ & vän & $\begin{array}{l}\text { zvonä } \\
\text { gen. } \\
137\end{array}$ & & & & & & & \\
\hline $\begin{array}{l}\text { *borb } \\
\text { B/D }\end{array}$ & $\begin{array}{l}\text { bôr } \\
\text { böra }\end{array}$ & $\begin{array}{c}\text { bôr } \\
\text { böra } \\
164\end{array}$ & $\begin{array}{c}\text { bôr } \\
\text { böra } \\
164\end{array}$ & $\begin{array}{c}\text { bôr } \\
\text { borà } \\
54\end{array}$ & $\begin{array}{c}\text { bôr } \\
\text { b̄örä } \\
28\end{array}$ & $\begin{array}{l}\text { bôr } \\
\text { böra } \\
164\end{array}$ & $\begin{array}{l}\text { bôr } \\
\text { böra } \\
164\end{array}$ & $\begin{array}{c}\text { bôr } \\
\text { böra } \\
\text { öd bora } \\
26\end{array}$ & $\begin{array}{l}\text { bôr } \\
\text { böra } \\
34\end{array}$ \\
\hline $\begin{array}{l}\text { *lovb } \\
\text { B/D }\end{array}$ & $\begin{array}{l}\text { lôv } \\
\text { löva }\end{array}$ & & & & & & & & $\begin{array}{c}\text { lôv } \\
\text { lōvà̀ } \\
\text { dìo lōvoù } \\
27\end{array}$ \\
\hline
\end{tabular}

${ }^{26}$ According to Rešetar (1900: 46) these forms (which Vuk attests "in den südwestlichen Gegenden") are incorrect. 


\begin{tabular}{|c|c|c|c|c|c|c|c|c|c|}
\hline CSl & BCS & Klim & Punat & Sali & Kom. & Korč. & Lopud & Cavtat & Muo \\
\hline $\begin{array}{c}{ }^{*} \text { mostъ } \\
\text { B/D }\end{array}$ & $\begin{array}{l}\text { môst } \\
\text { mösta }\end{array}$ & $\begin{array}{c}\text { möst } \\
\text { mostä } \\
140\end{array}$ & $\begin{array}{c}\text { möst } \\
\text { mostä } \\
140\end{array}$ & & & $\begin{array}{c}\text { *mòst } \\
\text { mòsta } \\
140\end{array}$ & $\begin{array}{c}\text { môs } \\
\text { mòsta } \\
140\end{array}$ & & \\
\hline $\begin{array}{l}\text { *strojb } \\
\text { B/D (?) }\end{array}$ & $\begin{array}{l}\text { strôj } \\
\text { ströja }\end{array}$ & $\begin{array}{l}\text { strôj } \\
\text {-ojä } \\
157\end{array}$ & $\begin{array}{l}\text { strôj } \\
\text {-ojä } \\
157\end{array}$ & & $\begin{array}{c}\text { strôj } \\
20\end{array}$ & & & & \\
\hline $\begin{array}{c}\text { *bokb } \\
\text { D }\end{array}$ & $\begin{array}{c}\text { bôk } \\
\text { böka }\end{array}$ & & & $\begin{array}{c}\text { bôk } \\
\text { bokä } \\
36\end{array}$ & $\begin{array}{c}\text { bûk } \\
\text { bōkä } \\
13\end{array}$ & & & & \\
\hline $\begin{array}{c}\text { *brodb } \\
\mathrm{D} / \mathrm{C}\end{array}$ & $\begin{array}{l}\text { brôd } \\
\text { bröda }\end{array}$ & $\begin{array}{c}\text { brôd } \\
\text { bröd- } \\
\text { ōn } \\
139 \\
141\end{array}$ & $\begin{array}{c}\text { brôd } \\
\text { bröd- } \\
\text { ōn } \\
139 \\
141\end{array}$ & $\begin{array}{c}\text { brôd } \\
\text { bröda, } \\
\text { od } \\
\text { bröda, } \\
\mathrm{z} \\
\text { brödun } \\
39\end{array}$ & $\begin{array}{c}\text { brûd } \\
\text { bröda. } \\
\text { od } \\
\text { bröda } \\
17 \\
\text { brödon } \\
16\end{array}$ & $\begin{array}{c}\text { brôd } \\
141 \\
\text { bröd-on } \\
139\end{array}$ & & $\begin{array}{c}\text { brôd } \\
\text { bröda } \\
10 \\
\text { öd } \\
\text { broda } 9 \\
\text { brödu } \\
11 \\
\text { brödōm } \\
9\end{array}$ & $\begin{array}{c}\text { brôd } \\
22,23 \\
\text { nä brōd } \\
21, \\
\text { mâlì od } \\
\text { brō dua } \\
21\end{array}$ \\
\hline $\begin{array}{c}{ }^{*} \text { drobъ } \\
\text { C/D }\end{array}$ & $\begin{array}{l}\text { drôb } \\
\text { dröba }\end{array}$ & $\begin{array}{c}\text { drôb } \\
\text { drobà } \\
158\end{array}$ & $\begin{array}{c}\text { drôb } \\
\text { drobà } \\
158\end{array}$ & $\begin{array}{c}\text { drôb } \\
\text { dröba } \\
48\end{array}$ & & & & & $\begin{array}{c}\text { drôb } \\
\text { drobà } \\
29\end{array}$ \\
\hline $\begin{array}{l}\text { *gromb }^{\text {grom }} \\
\text { ( /C) }\end{array}$ & $\underset{\text { gròma }}{\text { grôma }}$ & & & $\begin{array}{c}\text { grôm/ } \\
\text { grûn } \\
\text { gröma } \\
37\end{array}$ & $\begin{array}{l}\text { grôm } \\
\text { gröma } \\
14\end{array}$ & & $\begin{array}{c}\text { grôm } \\
\text { gròma } \\
138\end{array}$ & $\begin{array}{c}\text { grôm } \\
\text { gròm- } \\
\text { ovi } \\
8\end{array}$ & $\begin{array}{c}\text { grôm } \\
\text { gromä } \\
19\end{array}$ \\
\hline$\underset{\mathrm{C}}{*_{\text {gnojb }}}$ & $\begin{array}{l}\text { gnôj } \\
\text { gnöja }\end{array}$ & & & & & & & & $\underset{27}{\text { iz gnöja }}$ \\
\hline${ }^{*}$ lojb & $\begin{array}{l}\text { lôj } \\
\text { löja }\end{array}$ & $\begin{array}{l}\text { lôj } \\
\text { löja } \\
145\end{array}$ & $\begin{array}{l}\text { lôj } \\
\text { löja } \\
145\end{array}$ & & & $\begin{array}{l}\text { lôj } \\
\text { löja } \\
145\end{array}$ & $\begin{array}{l}\text { lôj } \\
\text { löja } \\
145\end{array}$ & & \\
\hline \multicolumn{10}{|c|}{ COMMON SLAVIC LONG-VOWEL STEMS } \\
\hline $\begin{array}{c}* \text { dymъ } \\
\text { A }\end{array}$ & $\begin{array}{l}\text { dìm } \\
\text { dìma }\end{array}$ & & & & & & & & $\begin{array}{l}\text { dìm } \\
25\end{array}$ \\
\hline $\begin{array}{c}{ }^{*} \mathrm{krajb} \\
\mathrm{A}\end{array}$ & $\begin{array}{c}\text { krâj } \\
\text { kräja } \\
\text { kräjevi }\end{array}$ & $\begin{array}{c}\text { na krâj } \\
143 \\
\text { kräja } \\
147\end{array}$ & $\begin{array}{c}\text { na krâj } \\
143 \\
\text { kräja } \\
147\end{array}$ & $\begin{array}{c}\text { üza } \\
\text { krâj } \\
39 \\
\text { od } \\
\text { kräja } \\
37\end{array}$ & $\begin{array}{c}\text { krôj } 13 \\
\text { nis krôj } \\
16 \\
\text { krâja } \\
13 \\
\text { dõrse } \\
\text { kräja } \\
30\end{array}$ & $\begin{array}{c}\text { krâj } \\
\text { kràja } \\
147\end{array}$ & $\begin{array}{c}\text { krâj } \\
\text { kràja } \\
147\end{array}$ & & $\begin{array}{c}\text { krâj } \\
\text { kräja } \\
18 \\
\text { nis krâj } \\
18 \text { na } \\
\text { krâj } 29 \\
\text { s kräja } \\
19\end{array}$ \\
\hline $\begin{array}{c}\text { *kruxb } \\
\text { A }\end{array}$ & $\begin{array}{c}\text { krüh } \\
\text { krüha } \\
\text { (West) }\end{array}$ & $\begin{array}{l}\text { krüh } \\
152\end{array}$ & $\begin{array}{l}\text { krüh } \\
152\end{array}$ & & & $\begin{array}{c}\text { krüh } \\
152\end{array}$ & $\begin{array}{c}\text { krüh } \\
152\end{array}$ & $\begin{array}{c}\text { krüh } \\
\text { krüha } \\
17\end{array}$ & \\
\hline $\begin{array}{c}\text { *mělb } \\
\text { A? }\end{array}$ & & $\begin{array}{l}\text { mêl } \\
\text { mëla } \\
148\end{array}$ & $\begin{array}{c}\text { (mêlo } \\
-a) \\
148\end{array}$ & & & & & & \\
\hline $\begin{array}{c}* \text { rakb } \\
\text { A }\end{array}$ & $\begin{array}{c}\text { räk } \\
\text { *äka }\end{array}$ & $\begin{array}{l}\text { räk } \\
162\end{array}$ & $\begin{array}{l}\text { räk } \\
162\end{array}$ & $\begin{array}{l}\text { räk } \\
\text { racì } \\
27\end{array}$ & $\begin{array}{l}\text { räk } \\
\text { racì } \\
27\end{array}$ & $\begin{array}{l}\text { räk } \\
162\end{array}$ & $\begin{array}{l}\text { räk } \\
162\end{array}$ & $\begin{array}{l}\text { räk } \\
\text { räzi }\end{array}$ & $\begin{array}{c}\text { räk } \\
\text { räka } \\
\text { räki } 33\end{array}$ \\
\hline
\end{tabular}


The historical accentuation of masculine nouns in Čakavian and Štokavian ...

\begin{tabular}{|c|c|c|c|c|c|c|c|c|c|}
\hline $\mathrm{CS} 1$ & BCS & Klim & Punat & Sali & Kom. & Korč. & Lopud & Cavtat & Muo \\
\hline $\begin{array}{c}\text { *syrb } \\
\text { A }\end{array}$ & $\begin{array}{l}\text { sìr } \\
\text { *sìra }\end{array}$ & $\begin{array}{l}\text { sîr } \\
\text { sìra } \\
153\end{array}$ & $\begin{array}{l}\text { sîr } \\
\text { sìra } \\
153\end{array}$ & & & $\begin{array}{l}\text { sîr } \\
\text { sìra } \\
153\end{array}$ & $\begin{array}{l}\text { sìr } \\
\text { sîra } \\
153\end{array}$ & $\begin{array}{c}\text { sìr } \\
153\end{array}$ & sìr 26 \\
\hline $\begin{array}{c}* \text { větrı } \\
\mathrm{A}\end{array}$ & $\begin{array}{l}\text { vjëtar } \\
\text { vjëtra }\end{array}$ & $\begin{array}{l}\text { vëtōr } \\
\text {-tra } \\
137\end{array}$ & $\begin{array}{l}\text { vëtār } \\
\text {-tra } \\
137\end{array}$ & $\begin{array}{c}\text { vìtar } \\
\text { vìtra } \\
36, \\
\text { od } \\
\text { vïtra } \\
37\end{array}$ & $\begin{array}{l}\text { vitra } \\
\text { gen. } \\
14\end{array}$ & $\begin{array}{l}\text { vìtār } \\
\text {-tra } \\
137\end{array}$ & $\begin{array}{c}\text { vjëtar } \\
\text {-tra } \\
137\end{array}$ & $\begin{array}{c}\text { vjëtar } \\
\text {-tra } \\
7\end{array}$ & $\begin{array}{l}\text { vjëtar } \\
\text { vjëtra } \\
19\end{array}$ \\
\hline $\begin{array}{c}* \text { volxb } \\
\mathrm{A}\end{array}$ & $\begin{array}{l}\text { Vläh } \\
\text { Vläha }\end{array}$ & $\begin{array}{l}\text { Vläh } \\
151\end{array}$ & $\begin{array}{l}\text { Vläh } \\
151\end{array}$ & & & $\begin{array}{l}\text { Vläh } \\
151\end{array}$ & & & \\
\hline $\begin{array}{c}*_{\text {Vbrčb }} \\
\text { A? }\end{array}$ & $\begin{array}{c}v \ddot{r c ̌ c} \\
v \ddot{c} a\end{array}$ & & & & $\begin{array}{c}\text { vârc } \\
\text { vārcà } \\
20\end{array}$ & & & & \\
\hline $\begin{array}{c}* \text { xlěbs } \\
\text { A }\end{array}$ & $\begin{array}{l}\text { hljëb } \\
\text { hljëba }\end{array}$ & $\begin{array}{l}\text { hïb } \\
152\end{array}$ & $\begin{array}{c}\text { hljib } \\
152\end{array}$ & & & & & & \\
\hline $\begin{array}{c}\text { *dělı } \\
\text { B }\end{array}$ & $\begin{array}{c}\text { dìo } \\
\text { dìjela } \\
\text { dijèlovi }\end{array}$ & & & & $\begin{array}{c}\text { dîl } \\
\text { dīlä } \\
22\end{array}$ & & & $\begin{array}{c}\text { dìo } \\
\text { dijela } \\
19\end{array}$ & $\begin{array}{c}\text { dìo } \\
\text { dijjēla } \\
27\end{array}$ \\
\hline $\begin{array}{c}{ }^{* k r i z ̌ b} \\
\mathrm{D} / \mathrm{B}\end{array}$ & $\begin{array}{l}\text { krîzz } \\
\text { kríža }\end{array}$ & & & & 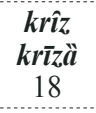 & & & & \\
\hline $\begin{array}{c}* \text { moldjb } \\
\mathrm{B}\end{array}$ & $\begin{array}{l}\text { mlâđ } \\
\text { *mlâđa }\end{array}$ & $\begin{array}{c}m l a \hat{j} \\
-\overline{a j j a ̈ ~} \\
148\end{array}$ & $\begin{array}{l}\text { *mlâj } \\
\text {-ajä } \\
148\end{array}$ & & & & & & \\
\hline $\begin{array}{c}\text { *spblžb } \\
\text { B }\end{array}$ & $\begin{array}{l}\text { pûž, -a } \\
\text { püževi/ } \\
\text { púževi }\end{array}$ & $\begin{array}{c}\text { pôz } \\
\text { pō̌̋ } \\
\text { pl. } 161\end{array}$ & $\begin{array}{l}\text { pûži } \\
161\end{array}$ & & $\begin{array}{l}\text { spûz } \\
\text { spüzùa } \\
27\end{array}$ & $\begin{array}{l}\text { spûži } \\
161\end{array}$ & $\begin{array}{l}\text { spûži } \\
161\end{array}$ & $\begin{array}{c}\text { spû́z } \\
\text { spúza } \\
24\end{array}$ & \\
\hline $\begin{array}{c}\text { *melčs } \\
\mathrm{B} ?\end{array}$ & $\begin{array}{c}\text { mlïječ; } \\
\text { mlïječ, -a } \\
\text { Ben. } \\
\text { mlijèčevi }\end{array}$ & $\begin{array}{l}\text { mlič } \\
160\end{array}$ & $\begin{array}{l}\text { mličc } \\
157 \\
160\end{array}$ & & & $\begin{array}{l}\text { mlï̌́ } \\
160\end{array}$ & $\begin{array}{c}\text { mlïječ, } \\
\text { mlijèča } \\
157\end{array}$ & & \\
\hline $\begin{array}{c}\text { *bergъ } \\
\mathrm{D}\end{array}$ & $\begin{array}{l}\text { brïjeg } \\
\text { brïjega }\end{array}$ & & & & & & & & $\begin{array}{c}\text { brijege } \\
\text { brijejegà } \\
19\end{array}$ \\
\hline $\begin{array}{l}\text { *listb } \\
\text { D }\end{array}$ & $\begin{array}{l}\text { list } \\
\text { lîsta }\end{array}$ & & & & & & & $\begin{array}{l}\text { lis } \\
\text { lîsta } \\
23\end{array}$ & \\
\hline $\begin{array}{l}{ }^{*} \text { Qzlb } \\
\text { D }\end{array}$ & $\begin{array}{l}\text { üzao } \\
\text { üzla }\end{array}$ & $\begin{array}{l}\text { üzōl } \\
\text { üzla } \\
147\end{array}$ & $\begin{array}{l}\text { üzāl } \\
147\end{array}$ & & & & $\begin{array}{l}\text { üzō } \\
\text { üzla } \\
147\end{array}$ & $\begin{array}{l}\text { üzō } \\
\text { üzla }\end{array}$ & \\
\hline $\begin{array}{c}\text { *ręd } \\
\text { D }\end{array}$ & $\begin{array}{l}\text { rêd } \\
\text { *rêda } \\
\text { rédovi }\end{array}$ & $\begin{array}{l}\text { dvâ } \\
\text { rêda } \\
161\end{array}$ & $\begin{array}{l}\text { dvâ } \\
\text { rêda } \\
161\end{array}$ & & & $\begin{array}{l}\text { dvâ } \\
\text { rêda } \\
161\end{array}$ & & $\begin{array}{c}\text { dvâ } \\
\text { rêda } \\
24\end{array}$ & $\begin{array}{c}\text { dvâ } \\
\text { rêda } \\
\text { p.? }\end{array}$ \\
\hline $\begin{array}{c}\text { *versb } \\
\mathrm{D} ?\end{array}$ & $\begin{array}{l}\text { vrïjes } \\
\text { vrïjesa }\end{array}$ & & & & & & & $\begin{array}{c}\text { vrijesōm } \\
12\end{array}$ & \\
\hline $\begin{array}{c}\text { *žerbъ } \\
D\end{array}$ & $\begin{array}{l}\text { žrïjeb } \\
\text { žrijeba }\end{array}$ & & & & $\begin{array}{c}\text { zdrîb } \\
\text { zdrībà } \\
17\end{array}$ & & & & \\
\hline
\end{tabular}




\section{REFERENCES}

Aleksandar BELIĆ, 1909: Zametki po čakavskim govoram. Izvestija otdelenija russkogo jazyka i slovesnosti Akademii Nauk 14, 181-266.

Ivan BROZ, F. IVEKOVIĆ, 1901: Rječnik hrvatskoga jezika. Zagreb: Štamparija Karla Albrechta (Jos. Wittasek).

Rima V. BULATOVA, Vladimir A. DYBO, Sergej L. NIKOLAEV, 1988: Problemy akcentologičeskix dialektizmov v praslavjanskom. Slavjanskoe jazykoznanie. X Meždunarodnyj s'ezd slavistov. Sofija, sentjabr' 1988 g. Doklady sovetskoj delegacii. Moskva: Nauka. 31-66.

Mirko DEANOVIĆ, 1958: Terminologia marinara e peschereccia a Ragusavecchia (Cavtat). Studia romanica et anglica zagrabiensia 5, 3-32.

- -, 1962: Lingvistički atlas Mediterana. Anketa u Boki Kotorskoj. Rad Jugoslavenske akademije znanosti i umjetnosti 327, 5-38.

- -, 1963: Izveštaj o anketi na Dugom Otoku za Lingvistički atlas Mediterana. Ljetopis Jugoslavenske akademije znanosti i umjetnosti 69, 339-341.

- -, 1966: Lingvistički atlas Mediterana II. Anketa na Visu (Komiža). Rad Jugoslavenske akademije znanosti i umjetnosti 344, 5-33.

- -, 1967: Lingvistički atlas Mediterana III. Anketa u Salima na Dugom otoku. Rad Jugoslavenske akademije znanosti i umjetnosti 348, 27-60.

Mirko DEANOVIĆ, Ive JELENOVIĆ, 1958: Pomorski i ribarski nazivi na Krku, Korčuli i Lopudu. Zbornik Instituta za historijske nauke u Zadru 2, 133-171.

Vladimir A. DYBO, Galina I. ZAMJATINA, Sergej L. NIKOLAEV,1990: Osnovy slavjanskoj akcentologii. Moskva: Nauka.

- -,1993: Osnovy slavjanskoj akcentologii. Slovar'. Neproizvodnye osnovy mužskogo roda. Vyp. 1. Moskva: Nauka.

Maks FASMER, 1958/1986: Ètimologičeskij slovar' russkogo jazyka. (Perevod s nemeckogo i dopolnenija člena-korrespondenta AN SSSR O. N. Trubačeva. Izdanie vtoroe, stereotipnoe. V četyrex tomax.) Moskva: "Progress".

H. P. HOUTZAGERS, 1986: The Čakavian dialect of Orlec on the island of Cres (Studies in Slavic and General Linguistics, 5). Amsterdam: Rodopi.

Mate HRASTE, 1935: Čakavski dijalekat ostrva Hvar. Biblioteka južnoslovenskog filologa $14-16,1-56$.

Mate HRASTE, Petar ŠIMUNOVIĆ (unter Mitarbeit und Redaktion von Reinhold Olesch), 1979: Čakavisch-deutsches Lexikon. Teil 1. Köln Wien: Böhlau Verlag. (Slavistische Forschungen 25/1).

- -, 1983: Čakavisch-deutsches Lexikon. Teil 3. Čakavische Texte. Köln Wien: Böhlau Verlag. (Slavistische Forschungen 25/3).

Vladislav M. ILLIČ-SVITYČ, 1963: Imennaja akcentuacija $v$ baltijskom i slavjanskom. Sud'ba akcentuacionnyx paradigm. Moskva: Izdatel'stvo Akademii nauk SSSR. 
Pavle IVIĆ, 1958: Die serbokroatischen Dialekte: Ihre Struktur und Entwicklung. S'Gravenhage: Mouton.

Ive JELENOVIĆ, 1962: Etnološki prilozi iz Dobrinja na otoku Krku. Zbornik za narodni život i običaje južnih slovena 40, 221-240.

Blaž JURIŠIĆ, 1973: Rječnik govora otoka Vrgade. Uspoređen s nekim čakavskim $i$ zapadnoštokavskim govorima. II dio, rječnik. Zagreb.

Mate KAPOVIĆ, 2008: Razvoj hrvatske akcentuacije. Filologija 51, 1-39.

Vuk Stef. KARADŽIĆ, 1849: Srpske narodne poslovice. U Beču u štampariji Jermenskoga manastira.

Keith LANGSTON, 2006: Čakavian prosody. The Accentual patterns of the Čakavian dialects of Croatian. Bloomington: Slavic.

- -, 2007: Common Slavic accentual paradigm (d): A reevaluation of evidence from Čakavian. Tones and Theories: Proceedings of the International Workshop on Balto-Slavic Accentology (Zagreb, 1-3 July 2005). Eds. Mate Kapović and Ranko Matasović. Institut za hrvatski jezik i jezikoslovlje. Zagreb. 121-150.

Ive LUKEŽIĆ, Marija TURK, 1998: Govori otoka Krka. Rijeka: Libellus.

Miloš MOSKOVLJEVIĆ,1972: Govor ostrva Vis. In R. V. Bulatova, red. Issledovanija po serboxorvatskomu jazyku. Moskva. 105-138.

Milan REŠETAR, 1900: Die serbokroatische Betonung südwestlicher Mundarten. Wien: Alfred Hölder (Schriften der Balkankommission der Kaiserliche Akademie der Wissenschaften, Linguistische Abteilung. Südslavische Dialektstudien, 1).

- -, 1907: Der štokavische Dialekt. Wien: Alfred Hölder (Schriften der Balkankommission der Kaiserliche Akademie der Wissenschaften, Linguistische Abteilung. Südslavische Dialektstudien, 8).

Miriam-Maria SCHRAGER, 2011: Accentuation of masculine monosyllabic nouns of Susak speakers in New Jersey. Baltistica VII Priedas (Proceedings of the Sixth International Workshop on Baltoslavic Accentology). 29-47.

Petar SKOK, 1973: Etimologijski rječnik hrvatskoga ili srpskoga jezika. 3 knj. Zagreb: Jugoslavenska akademija znanosti i umjetnosti.

Petar ŠIMUNOVIĆ, 1981: Komiža (OLA 42). Fonološki opisi srpskohrvatskih/hrvatskosrpskih, slovenačkih i makedonskih govora obuhvaćenih opšteslovenskim lingvističkim atlasom. Sarajevo: Akademija nauka i umjetnosti Bosne i Hercegovine (Posebna Izdanja 9). 259-265.

- -, 2009: Rječnik bračkih čakavskih govora. Drugo dopunjeno i popravljeno izdanje. Zagreb: Golden marketing - Tehnička knjiga.

Vaso, TOMANOVIĆ, 1935: Akcenat u govoru sela Lepetana (Boka Kotorska). Južnoslovenski filolog 14, 59-141.

Willem VERMEER, 1982: On the principal sources for the study of Čakavian dialects with neocircumflex in adjectives and e-presents. South Slavic and Balkan Linguistics (Studies in Slavic and General Linguistics, 2). 279-341. 
--, 1984a: On clarifying some points of Slavonic accentology: the quantity of the thematic vowel in the present tense and related issues. Folia Linguistica Historica 5/2, 331-395.

- -, 1984b: Opozicija tipa "živo/neživa" u množini u jednom čakavskom sistemu (Omišalj). Naučni sastanak slavista u Vukove dane i referati i saopštenija 13/1, 275-288 (as per the 2009 on-line version at http://www.hum2.leidenuniv.nl/pdf/S\&R/publicaties/ vermeer_1984b_Opozicija_Omisalj.pdf).

- -, 2001: Critical observations on the modus operandi of the Moscow Accentological School. In Lehfeldt, Werner. Einführung in die morphologische Konzeption der slavischen Akzentologie. 2., verbesserte und ergänzte Auflage mit einem Appendix von Willem Vermeer. Verlag Otto Sagner: München. (Vorträge und Abhandlungen zur Slavistik, Band 42). 131-161.

Stjepan VUKUŠIĆ, 1984: Nacrt hrvatske naglasne norme na osnovi zapadnog dijalekta. Pula: Istarska naklada.

\section{ZGODOVINSKO NAGLAŠEVANJE SAMOSTALNIKOV MOŠKEGA SPOLA V ČAKAVSKIH IN ŠTOKAVSKIH DALMATINSKIH NAREČJIH V LUČI DEANOVIĆEVEGA LINGVISTIČKEGA ATLASA MEDITERANA}

Prispevek se osredinja na podatke projekta Lingvistički atlas Mediterana Mirka Deanovića in jih vključuje v raziskavo naglaševanja samostalnikov moškega spola v (čakavskih in štokavskih) bosanskih, hrvaških ter srbskih narečjih (okrajšano angl. BCS dialects) na območju dalmatinske obale in otokov. V ospredju je dokazovanje morebitne četrte praslovanske naglasne paradigme (AT-D), znane tudi kot Illič-Svityčev arhaizem. Gre za tematiko, ki je bila v središču znanstvenih razprav, posvečenih dokazovanju praslovanskega naglasnega tipa $d$ in njegovemu nasprotovanju.

Avtor opaža, da Deanovićevi podatki potrjujejo naglasni tip d (AT-D) v centralnih čakavskih narečjih v petih osnovah s kratkimi samoglasniki: (1) *bokb, (2) *borz, (3) *brodz, (4) *drobb, (5) *lovъ in v dveh osnovah z dolgimi samoglasniki: (1) *bergz, (2) *žerbъ. Ob tem avtor meni, da Deanovićevo gradivo pri širjenju geografskega obsega naglasnega tipa $d$ dopušča vključevanje severozahodnega in jugovzhodnega čakavskega ter Zeta-Lovćenskega štokavskega narečja na območju Boke Kotorske. Vključevanje Deanovićevega gradiva, ki se nanaša na naglasni tip $d$, v praslovansko naglasno paradigmo ostaja predmet nadaljnjih raziskav. 